\title{
Ostrich produce cross-reactive neutralization antibodies against pandemic influenza virus A/H1N1 following immunization with a seasonal influenza vaccine
}

\author{
KAZUHIDE ADACHI ${ }^{1}$, KENTARO TAKAMA ${ }^{1}$, MASAYA TSUKAMOTO $^{1}$, MARIE INAI $^{1}$, \\ EKOWATI HANDHARYANI ${ }^{2}$, SATOSHI HIROI ${ }^{3}$ and YASUHIRO TSUKAMOTO ${ }^{1}$ \\ ${ }^{1}$ Department of Animal Hygiene, Graduate School of Environmental and Biological Sciences, \\ Kyoto Prefecture University, Shimogamo, Kyoto 606-8522, Japan; ${ }^{2}$ Faculty of Veterinary Medicine, \\ Bogor Agricultural University, JL. Agatis, Kampus IPB Darmaga, Bogor 16680, Indonesia; ${ }^{3}$ Department of Virology, \\ Osaka Prefectural Institute of Public Health, Higashinari-ku, Osaka City, Osaka 537-0025, Japan
}

Received October 6, 2010; Accepted November 12, 2010

DOI: $10.3892 /$ etm.2010.180

\begin{abstract}
An outbreak of influenza in 2009 was found to be caused by a novel strain of influenza virus designated as pandemic influenza $\mathrm{A} / \mathrm{H} 1 \mathrm{~N} 1$ 2009. Vaccination with recent seasonal influenza vaccines induced little or no cross-reactive antibody response to the pandemic influenza virus A/H1N1 2009 in any age group in human populations. Accordingly, most people had low immunity against this pathogen, thus resulting in the worldwide spread of the infection to produce a so-called 'pandemic'. This report presents the important finding that ostrich eggs generate cross-reactive antibodies to the pandemic influenza virus $\mathrm{A} / \mathrm{H} 1 \mathrm{~N} 1$ following immunization of female ostrich with a seasonal influenza vaccine. This simple method produced a large amount of antibodies against influenza viruses by one female ostrich. An enzyme-linked immunosorbent assay (ELISA) and immunocytochemistry indicated that the ostrich antibodies possessed strong cross-reactivity to the pandemic $\mathrm{A} / \mathrm{H} 1 \mathrm{~N} 1$ as well as to the seasonal $\mathrm{A} / \mathrm{H} 1 \mathrm{~N} 1, \mathrm{~A} / \mathrm{H} 3 \mathrm{~N} 2$ and $\mathrm{B}$ viruses. The hemaggregation activities of erythrocytes induced by this pandemic strain were also inhibited by the ostrich antibodies. In addition, the cytopathological effects of infection with a pandemic virus on MDCK cells were clearly inhibited in co-cultures with the ostrich antibodies, thereby indicating the neutralization of viral infectivity in the cells. In conclusion, cross-reactive neutralization antibodies against pandemic influenza virus A/H1N1 2009 were successfully generated in ostrich eggs produced by females immunized with seasonal influenza viral vaccine.
\end{abstract}

Correspondence to: Professor Yasuhiro Tsukamoto, Department of Animal Hygiene, Graduate School of Biology and Environmental Sciences, Kyoto Prefecture University, 1-5 Nakaragicho, Shimogamo, Kyoto 606-8522, Japan

E-mail: ytsuka@kpu.ac.jp

Key words: influenza virus, pandemic, H1N1, antibody, ostrich

\section{Introduction}

Public health officials in Mexico City were confronted with an outbreak of influenza late in the 2009 influenza season. The 2009 pandemic H1N1 virus contained a unique combination of genes from both North American and Eurasian swine lineages that had not been previously indentified in either swine or human populations $(1,2)$. The pandemic 2009 H1N1 hemagglutinin (HA) was found to be antigenically and genetically distinct from the HA of contemporary human seasonal influenza H1N1 viruses, but had a greater similarity to the swine $\mathrm{H} 1 \mathrm{~N} 1$ influenza virus that caused an influenza outbreak among military recruits in Fort Dix, New Jersey, in 1976 (1,3). Little is known about the level of pre-existing immunity to 2009 $\mathrm{H} 1 \mathrm{~N} 1$ in humans, which is one of the determining factors for susceptibility to a novel influenza virus. Vaccination has been a mainstay of influenza prevention, with annual vaccination recommended for adults and children at high risk. However, vaccination with recent seasonal influenza vaccines induced little or no cross-reactive antibody response to the pandemic A/ H1N1 2009 influenza virus in any age group in human populations (4). Accordingly, most people had low immunity against this novel pathogen, thus resulting in the worldwide spread of the infection to produce a so-called 'pandemic'.

A convenient method for the mass production of antibodies has been developed using the female ostrich (Struthio camelus) $(5,6)$. The avian egg has proven to be an attractive source for the noninvasive production of antibodies, with applications in research, diagnosis and immunotherapy (7-9). In addition, the production of avian antibodies offers many advantages over mammalian antibodies with regard to the specificity for antigens, production cost and their uses (7). The predominant class of immunoglobulin in birds is immunoglobulin yolk (IgY), which is transferred from the serum to the yolk to confer passive immunity to the embryo $(10,11)$. The ostrich grows to be $250 \mathrm{~cm}$ in height and $160 \mathrm{~kg}$ in weight, and their life span is appoximately 60 years. Ostrich eggs weigh approximately $1.5 \mathrm{~kg}$ and are 30-fold larger than chicken eggs. Ostrich can lay one hundred eggs every year. It is possible to purify about 
2-4 g of IgY per ostrich egg. Accordingly, approximately $400 \mathrm{~g}$ of IgY can be obtained from only one ostrich in the course of a year. Therefore, the ostrich egg might provide an excellent source of antibodies for industrial purposes (5).

The present study demonstrated that a large amount of cross-reactive and neutralizing antibodies to the pandemic influenza virus $\mathrm{A} / \mathrm{H} 1 \mathrm{~N} 1$ was generated by the ostrich using a simple and economical method involving immunization with a seasonal influenza viral vaccine.

\section{Materials and methods}

Generation of antibodies against seasonal influenza virus $H A$ antigens. A mixture of HA antigens of vaccine strains of seasonal influenza virus, A/NewCaledonia/20/99 (H1N1), A/ Hiroshima/52/2005 (H3N2) and B/Malaysia (The Kitasato Institute Research Center for Biologicals, Japan) was used as antigens for the immunization of the ostrich. The female ostrich were immunized intramuscularly in the lumber region at multiple sites with $30 \mu \mathrm{g}$ of the mixture of HA. Boosters were administered every other week with each antigen. The eggs were then collected 4 weeks after the initial immunization. The yolk was separated from the albumin of the eggs and diluted 5-fold with TBS buffer [0.02 M Tris/HCl ( $\mathrm{pH} 7.5), 0.15$ $\mathrm{M} \mathrm{NaCl}$, and an initial 1/10-fold with $30 \%$ dextran sulfate in TBS and 2/3-fold with $2.5 \mathrm{M} \mathrm{CaCl}_{2}$ in TBS, and then stored at $4^{\circ} \mathrm{C}$ for at least $4 \mathrm{~h}$. The supernatant containing the $\mathrm{IgY}$ was collected by centrifugation $\left(10,000 \mathrm{x}\right.$ g at $4^{\circ} \mathrm{C}$ for $\left.15 \mathrm{~min}\right)$ and precipitated with $45 \%$ saturated ammonium sulfate. The solution was centrifuged again at $10,000 \mathrm{x}$ g at $4^{\circ} \mathrm{C}$ for $15 \mathrm{~min}$. The precipitate was then redissolved in TBS and dialyzed against PBS. Finally, the purified antibody solutions were verified by $10 \%$ SDS-PAGE under non-reducing conditions and stained with Coomassie Brilliant Blue (CBB).

Enzyme-linked immunosorbent assay (ELISA). Each well of a polystyrene ELISA plate (Sumitomo Bakelite, Japan) was coated with $0.2 \mu \mathrm{g}$ of HA antigens from each vaccine strain and pandemic A/H1N1 (Protein Science, USA), and the plate was incubated overnight at $4^{\circ} \mathrm{C}$. Each of the following incubation steps was preceded by washing the wells twice with PBS containing $0.05 \%$ Tween-20. The wells were blocked for nonspecific binding by the addition of a commercial blocking buffer (DS Pharma Biomedical, Japan) and incubated at $37^{\circ} \mathrm{C}$ for $2 \mathrm{~h}$. Serial dilutions of purified ostrich IgY generated by the seasonal influenza vaccine immunization were added vertically to the wells and kept for incubation at $37^{\circ} \mathrm{C}$ for $1 \mathrm{~h}$. The HRP-conjugated rabbit IgG against ostrich IgY (5) diluted 1:5,000 in PBS was dispensed into each well. The plate was incubated for $1 \mathrm{~h}$ at $37^{\circ} \mathrm{C}$ and washed. A substrate buffer containing TMB (Sumitomo Bakelite, Japan) was added to each well and kept for incubation at $37^{\circ} \mathrm{C}$ for $15 \mathrm{~min}$. The reaction was terminated by the addition of a stopping reagent (1.25 M sulfuric acid). The absorbance was recorded at $450 \mathrm{~nm}$ using an ELISA plate reader (DS Pharma Biomedical).

Influenza viruses. Seasonal influenza viruses [A/Osaka/ 309/2007 (H1N1), A/Osaka/2587/2005 (H3N2) and B/Osaka 21/2005] and a pandemic virus [A/Osaka/2040/2009 (H1N1) pdm] cloned from patients in Osaka Prefecture, Japan, were used throughout this study. The viral solutions were titered as TCID $_{50}$ using a cell culture system (MDCK cells) onto 96-well microtiter plates by serial 4-fold dilutions of the samples in the routine manner.

Immunocytochemistry. MDCK cells were independently infected with each influenza virus $\left(10^{2} \mathrm{TCID}_{50}\right)$ for $2-5$ days at $35^{\circ} \mathrm{C}$. The infected cells were fixed with $10 \%$ buffered formalin for immunocytochemistry. The cells were washed in PBS, incubated with the ostrich IgY generated by seasonal influenza vaccine immunization $(1: 4000)$ for $1 \mathrm{~h}$ at $37^{\circ} \mathrm{C}$ and incubated with FITC-conjugated rabbit $\operatorname{IgG}$ (1:4000) against ostrich IgY (5) following a sufficient number of washes in PBS. Finally, the specific signal was observed using fluorescence microscopy.

Hemagglutination inhibition (HI) test. Serial dilutions of ostrich IgY were mixed with 8-HA units of each influenza virus in clear 96-well micro-test polystyrene assay plates (Becton Dickinson, USA). The plates were incubated for $30 \mathrm{~min}$ at room temperature. Guinea pig erythrocytes were added, pipetted gently, and incubation was carried out for another $45 \mathrm{~min}$ at room temperature. Each well was observed, and the HI titers were scored based on the HA titer with immune IgY versus the HA titer with preimmune IgY (a higher ratio indicates a stronger inhibitory activity of the antibody against the pandemic influenza virus).

Neutralization assays for influenza virus infection. Serial dilutions of ostrich IgY were mixed at a ratio of 1:1 with influenza viruses at $10^{2} \mathrm{TCID}_{50}$, incubated for $1 \mathrm{~h}$ at $37^{\circ} \mathrm{C}$, and transferred to a microtiter plate with an MDCK cell monolayer. The cultures were incubated for 2-3 days at $35^{\circ} \mathrm{C}$ and inspected to determine the cytopathic effect (CPE). The neutralizing titer, expressed as the reciprocal of the IgY dilution at which virus growth is inhibited by $50 \%$, was calculated by the number of virus negative wells and the IgY dilution (12).

\section{Results}

Cross-reactive antibody responses of ostrich $\operatorname{IgY}$ to the pandemic influenza virus $A / H 1 N 1$. IgY was purified from eggs produced by female ostrich immunized with a seasonal influenza vaccine. The molecular weight of purified IgY was 200 kDa (SDS-PAGE; data not shown). Each immunized ostrich egg yielded $\sim 4 \mathrm{~g}$ of $\mathrm{IgY}$. The reactivity of the $\operatorname{IgY}$ to the seasonal and pandemic influenza viruses was estimated by ELISA. The antibody titers for each antigen of the seasonal A/H1N1, A/H3N2 and B viruses were increased dramatically in the ostrich yolk after immunization (Table I). In addition, it appeared that the antibody had a high cross-reactivity to the pandemic influenza viral antigens.

The reactivity of the ostrich IgY to the infectious influenza viruses was examined by immunocytochemistry. MDCK cells were infected with each seasonal influenza virus and pandemic influenza virus $\mathrm{A} / \mathrm{H} 1 \mathrm{~N} 1$. The infected cells were fixed and reacted with IgY generated by the seasonal influenza vaccine immunization. The cytoplasm of the cells infected with the seasonal $\mathrm{A} / \mathrm{H} 1 \mathrm{~N} 1, \mathrm{~A} / \mathrm{H} 3 \mathrm{~N} 2$ and $\mathrm{B}$ viruses was strongly labeled with the IgY (Fig. 1). In contrast, preimmune 
Table I. Cross-reactivities of ostrich antibodies ( $\operatorname{IgY}$ ) generated by seasonal influenza vaccine immunization.

Antibody titer against the indicated influenza virus HA antigens

\begin{tabular}{lcccc}
\cline { 2 - 3 } Antibody & \multicolumn{3}{c}{ Seasonal influenza viruses } & Pandemic influenza virus \\
\cline { 2 - 4 } & $\mathrm{A} / \mathrm{H} 1 \mathrm{~N} 1$ & $\mathrm{~A} / \mathrm{H} 3 \mathrm{~N} 2$ & $\mathrm{~B}$ & $2009 \mathrm{~A} / \mathrm{H} 1 \mathrm{~N} 1$ \\
\hline Ostrich IgY & 102,400 & 204,800 & 102,400 & 51,200
\end{tabular}

The antibody titer against the seasonal and pandemic influenza viruses was estimated by ELISA. The ELISA titers against the seasonal influenza viruses [A/Osaka/309/2007 (H1N1), A/Osaka/2587/2005 (H3N2), B/Osaka/21/2005] were markedly increased in ostrich egg yolk (IgY) at 4 weeks post-immunization. In addition, the reactivity to a pandemic influenza virus [A/Osaka/2040/2009 (H1N1)pdm] was also increased in the IgY. This indicates that the antibody was also cross-reactive to the pandemic influenza virus A/H1N1. The antibody titers were defined as the reciprocal of the highest dilution (initial volume, $2 \mathrm{mg} / \mathrm{ml}$ ) that produced an ELISA signal twice as intense as the signal from equivalently diluted preimmune IgY.

Seasonal influenza

A/H1N1

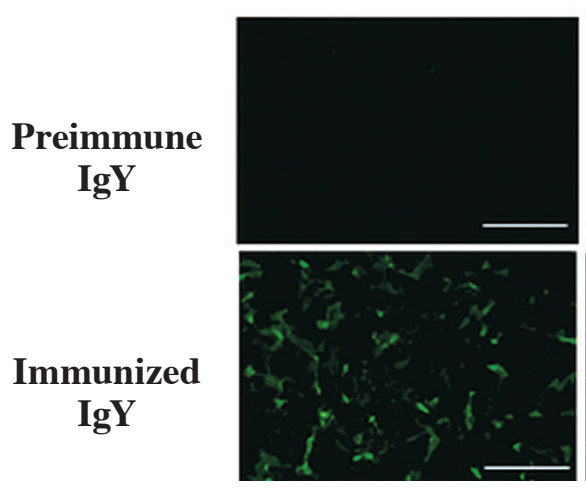

A/H3N2

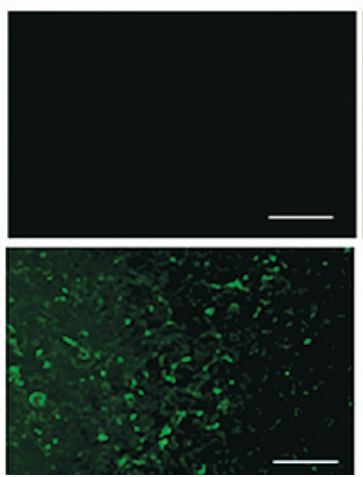

Pandemic influenza

B

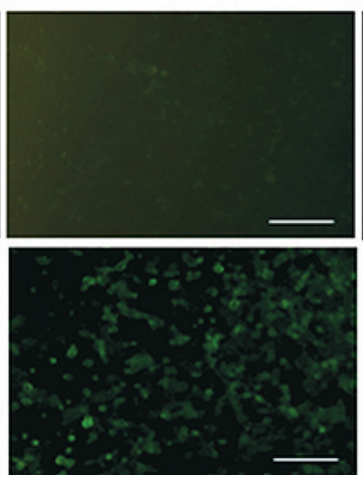

2009 A/H1N1

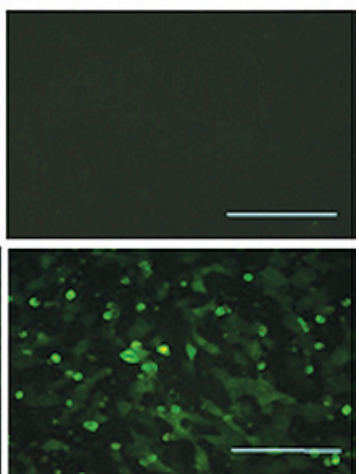

Figure 1. Immunocytochemistry of influenza virus-infected MDCK cells. MDCK cells were infected with seasonal influenza viruses [A/Osaka/309/2007 (H1N1), A/Osaka/2587/2005 (H3N2), B/Osaka/21/2005] and pandemic A/H1N1 [A/Osaka/2040/2009 (H1N1)pdm)]. The cells were fixed 5 days after infection, reacted with ostrich IgY, and then visualized with an FITC-conjugated secondary antibody. None of the cells infected with each virus were stained by preimmune IgY. In contrast, the cells infected with each seasonal influenza virus were strongly stained with the IgY produced by ostrich immunized with the seasonal influenza vaccine. Notably, the IgY cross-reacted with the cells infected with the pandemic A/H1N1 virus. Bars, $100 \mu \mathrm{m}$.

IgY did not react with the infected cells. Notably, the cells infected with the pandemic influenza virus also reacted with the IgY. This demonstrated the cross-reactivity of the ostrich antibodies to the pandemic influenza virus $\mathrm{A} / \mathrm{H} 1 \mathrm{~N} 1$, thereby supporting the ELISA findings.

Inhibition of hemaggregation activities of pandemic influenza virus A/HIN1 by ostrich IgY. The HA activities of the influenza viruses were estimated using erythrocytes, since the viral strains in this study originated from sporadic cases of infection and their characteristics had not yet been clarified. The highest dilutions of viral fluids showing hemaggregation were scored as a single HA unit. Each strain of the influenza virus was used for $\mathrm{HI}$ testing at 8-HA units.

Hemaggregation by the seasonal A/H1N1, A/H3N2 and $\mathrm{B}$ viruses was dramatically inhibited by the ostrich IgY. Importantly, the hemaggregation activities of the pandemic influenza virus $\mathrm{A} / \mathrm{H} 1 \mathrm{~N} 1$ were also impeded by the $\mathrm{IgY}$ (Table II). Accordingly, this antibody blocked the HA on the surface of the pandemic A/H1N1 virus as well as on the seasonal influenza viruses, and also inhibited the interaction of HA and erythrocytes, thereby leading to the inhibition of hemaggregation.

Neutralization assays for pandemic influenza virus A/H1N1 infection. The seasonal and pandemic influenza viruses were reacted with the ostrich $\mathrm{IgY}$ followed by inoculation into MDCK cells. The degree of neutralization was determined by the observation of CPE after 4 days of inoculation. As shown in Table III, the IgY strongly inhibited the infectivity of all seasonal influenza viruses, A/H1N1, A/H3N2 and B; even a small volume of IgY obstructed the infections of the viruses in the MDCK cells. Notably, the infection of pandemic influenza virus A/H1N1 to MDCK cells was also strongly inhibited by the ostrich IgY. The IgY appeared to bind to the HA of the pandemic influenza virus as well as of the seasonal viruses, and blocked the interaction between viral particles and the receptors on cells, thus leading to the inhibition of viral infectivity. 
Table II. Inhibitory activity of ostrich IgY on hemaggregations by the pandemic influenza virus A/H1N1.

\begin{tabular}{|c|c|c|c|c|}
\hline & \multicolumn{3}{|c|}{ Seasonal influenza viruses } & \multirow{2}{*}{$\frac{\text { Pandemic influenza virus }}{2009 \text { A/H1N1 }}$} \\
\hline & $\mathrm{A} / \mathrm{H} 1 \mathrm{~N} 1$ & $\mathrm{~A} / \mathrm{H} 3 \mathrm{~N} 2$ & B & \\
\hline HI titer & 512 & 512 & 128 & 256 \\
\hline \multicolumn{5}{|c|}{$\begin{array}{l}\text { Guinea pig erythrocytes were reacted with seasonal influenza viruses [A/Osaka/309/2007 (H1N1), A/Osaka/2587/2005 (H3N2), B/ } \\
\text { Osaka/21/2005] and a pandemic virus [A/Osaka/2040/2009 (H1N1)pdm] after incubation with IgY. The activity of IgY against each of the } \\
\text { viruses was represented as HI by a titer ratio: 'the highest dilution of immune IgY indicating clear inhibition on hemaggregations' versus 'the } \\
\text { highest dilution of preimmune IgY indicating clear inhibition on hemaggregations'. Higher HI titers indicated strong inhibitory activity of the } \\
\text { antibody against aggregation by the viruses. Note that the ostrich IgY exhibits inhibitory activities on hemaggregation by a pandemic influenza }\end{array}$} \\
\hline
\end{tabular}

Table III. Neutralizing activities of ostrich IgY against the infectivities of seasonal and pandemic influenza viruses.

\begin{tabular}{|c|c|c|c|c|}
\hline \multirow[b]{3}{*}{ Antibody (IgY) } & \multicolumn{4}{|c|}{ Neutralizing titers $(\mu \mathrm{g} / \mathrm{ml})$} \\
\hline & \multicolumn{3}{|c|}{ Seasonal influenza viruses } & \multirow{2}{*}{$\frac{\text { Pandemic influenza virus }}{2009 \mathrm{~A} / \mathrm{H} 1 \mathrm{~N} 1}$} \\
\hline & $\mathrm{A} / \mathrm{H} 1 \mathrm{~N} 1$ & $\mathrm{~A} / \mathrm{H} 3 \mathrm{~N} 2$ & $\mathrm{~B}$ & \\
\hline Preimmune IgY & $>384.0$ & $>384.0$ & $>384.0$ & $>384.0$ \\
\hline Immunized IgY & 2.6 & 8.9 & 22.3 & 11.2 \\
\hline
\end{tabular}

Neutralization assays were performed using MDCK cells infected with seasonal influenza viruses [A/Osaka/309/2007 (H1N1), A/ Osaka/2587/2005 (H3N2), B/Osaka/21/2005] and a pandemic virus [A/Osaka/2040/2009 (H1N1)pdm]. The titers are indicated as the mean of $50 \%$ inhibition on CPE at 5 days post-infection. Note that a pandemic influenza virus as well as all of the seasonal influenza viruses were inhibited with a small volume of immunized ostrich IgY.

\section{Discussion}

Hemagglutinin is essential for viral binding to cells and entrance into host cells. Therefore, these antigens are widely used in the vaccination against influenza in humans (13). The inhibition of HA antigens by antibodies is useful for protecting against these viral infections.

The pandemic influenza virus belongs to strain $\mathrm{A} / \mathrm{H} 1 \mathrm{~N} 1$, but its HA is genetically distinct from the HA of seasonal A/H1N1 (2). Vaccination with seasonal influenza vaccines, even when formulated with oil-in-water adjuvants, was found to provide little or no benefit to any age group in human populations with respect to an increase in cross-reactive neutralizing antibodies against pandemic A/H1N1 (4). Importantly, the present study demonstrated that vaccination of a seasonal trivalent influenza HA vaccine into the ostrich resulted in a marked increase in the level of cross-reactive antibody to pandemic influenza A/ H1N1. One important finding of the present study was the observation that ostrich IgY obstructed the hemaggregation activities of the pandemic influenza virus A/H1N1. The HA antigens on the pandemic influenza virus $\mathrm{A} / \mathrm{H} 1 \mathrm{~N} 1$ might be masked by ostrich antibodies, thus resulting in the effective blocking of viral adsorption into the cells. The neutralization activities of ostrich antibodies were assessed using living cells to confirm this paradigm. The infection of pandemic influenza viruses from patients was prevented by the IgY, and the $\mathrm{CPE}$ of MDCK cells was dramatically inhibited by the antibodies.
Therefore, ostrich antibodies might inhibit the entrance of the pandemic influenza virus into cells by blocking HA activities, thus resulting in the escape of cells from viral infection. The ostrich IgY against seasonal A/H1N1 in the trivalent vaccine had cross-reactivity to pandemic $\mathrm{A} / \mathrm{H} 1 \mathrm{~N} 1$, because of the antigenic similarity among strains of A/H1N1. Ongoing studies are underway to determine the mechanism by which ostrich produce cross-reactive neutralizing antibodies to pandemic influenza virus A/H1N1 by immunization with seasonal influenza vaccine.

There is an increasing need for the development of antibodies for research, diagnostic and therapeutic purposes. However, antibodies from experimental mammals, including the mouse and rabbit, are not suited for industrial use because of their high production cost. The avian egg has proven to be an attractive source for the non-invasive production of antibodies, with applications in research, diagnosis and immunotherapy $(8,9)$. A simple and economical method has been developed for the mass production of antibodies, and $4 \mathrm{~g}$ of $\mathrm{IgY}$ can be purified from one yolk; thus, $400 \mathrm{~g}$ of antibodies can be obtained from one female ostrich in one year (5). This suggests that anti-pandemic influenza virus antibodies can be provided in large quantities at a relatively low price using ostrich. Accordingly, the ostrich egg might provide an excellent source of antibodies for industrial purposes.

Recently, various types of facial masks and air-conditioner filters have been used for the prevention of airborne infections. 
However, the small influenza virus can pass through currently used filters, thus resulting in human infection, as the virus is still alive even after drying (14-16). Therefore, a high grade filter employing new prevention mechanisms must be developed. Ostrich IgY is being applied to filters, and can protect against influenza viruses by antigen-antibody reactions. In the present study, a large amount of cross-reactive neutralization antibodies against the various influenza viruses, including pandemic $\mathrm{A} / \mathrm{H} 1 \mathrm{~N} 1$, was produced in a cost-effective manner, indicating the potential of ostrich antibodies for industrial purposes. Filters impregnated with ostrich antibodies may therefore become a powerful tool for protecting humans against pandemic influenza viruses.

\section{Acknowledgements}

We thank Dr Tetsuo Kase at the Osaka Prefectural Institute of Public Health for providing the clinical strains of the influenza viruses. We also thank Dr Yoji Goto at The Kitasato Institute Research Center for Biologicals, Japan, for providing the HA antigens of the influenza virus vaccine strains. This study was supported in part by a Grant-in-Aid for Scientific Research (no. 21380182) from the Ministry of Education, Science, Sports and Culture, Japan.

\section{References}

1. Garten RJ, Davis CT, Russell CA, Shu B, Lindstrom S, Balish A, Sessions WM, Xu X, Skepner E, Deyde V, Okomo-Adhiambo M, Gubareva L, Barnes J, Smith CB, Emery SL, Hillman MJ, Rivailler P, Smagala J, De Graaf M, Burke DF, Fouchier RA, Pappas C, Alpuche-Aranda CM, López-Gatell H, Olivera H, López I, Myers CA, Faix D, Blair PJ, Yu C, Keene KM, Dotson PD Jr, Boxrud D, Sambol AR, Abid SH, St George K, Bannerman T, Moore AL, Stringer DJ, Blevins P, DemmlerHarrison GJ, Ginsberg M, Kriner P, Waterman S, Smole S, Guevara HF, Belongia EA, Clark PA, Beatrice ST, Donis R, Katz J, Finelli L, Bridges CB, Shaw M, Jernigan DB, Uyeki TM, Smith DJ, Klimov AI and Cox NJ: Antigenic and genetic characteristics of swine-origin 2009 A(H1N1) influenza viruses circulating in humans. Science 325: 197-201, 2009.

2. Novel Swine-Origin Influenza A (H1N1) Virus Investigation Team: Emergence of a novel swine-origin influenza A (H1N1) virus in humans. N Engl J Med 360: 2605-2615, 2009.
3. Nelson MI, Viboud C, Simonsen L, Bennett RT, Griesemer SB, St-George K, Taylor J, Spiro DJ, Sengamalay NA, Ghedin E, Taubenberger JK and Holmes EC: Multiple reassortment events in the evolutionary history of H1N1 influenza A virus since 1918. PLoS Pathog 4: e1000012, 2008.

4. Hancock K, Veguilla V, Lu X, Zhong W, Butler EN, Sun H, Liu F, Dong L, DeVos J, Gargiullo PM, Brammer TL, Cox NJ, Tumpey TM and Katz JM: Cross-reactive antibody responses to the 2009 pandemic H1N1 influenza virus. N Engl J Med 361: 1945-1952, 2009.

5. Adachi K, Handharyani E, Sari DK, Takama K, Fukuda K, Endo I, Yamamoto R, Sawa M, Tanaka M, Konisi I and Tsukamoto Y: Development of neutralization antibodies against highly pathogenic $\mathrm{H} 5 \mathrm{~N} 1$ avian influenza virus using ostrich (Struthio camelus) yolk. Mol Med Rep 1: 203-209, 2008.

6. Adachi K, Hagimori K, Kato H, Fukuda K, Kikuta M and Tsukamoto Y: Potential role of SC1, a cell adhesion molecule, in mammary gland tumors. Mol Med Rep 1: 219-224, 2008.

7. Schade R, Pfister C, Halatsch R and Henklein P: Polyclonal IgY antibodies from chicken egg yolk - an alternative to the production of mammalian IgG type antibodies in rabbits. ATLA 19: 403-419, 1991.

8. Schade R, Schniering A and Hlinak A: Polyclonal avian antibodies extracted from egg yolk as an alternative to the production of antibodies in mammals - a review. ALTEX 9: 43-56, 1992.

9. Gross M and Speck J: Avian yolk antibodies in diagnosis and research. Dtsch Tierarztl Wochenschr 103: 417-422, 1996.

10. Larsson A, Balow RM, Lindahl TL and Forsberg PO: Chicken antibodies: taking advantage of evolution - a review. Poult Sci 72: $1807-1812,1993$.

11. Leslie GA and Clem LW: Phylogeny of immunoglobulin structure and function. III. Immunoglobulins of the chicken. J Exp Med 130: 1337-1352, 1969.

12. Reed LJ and Muench H: A simple method of estimating fifty percent endo-points. Am J Hyg 27: 493-797, 1938.

13. Bosch FX, Orlinch M, Klenk HD and Rott R: The structure of the hemagglutinin, a determinant for the pathogenicity of influenza viruses. Virology 95: 197-207, 1979.

14. Wiwanitkit V: N-95 face mask for prevention of bird-flu virus: An appraisal of nanostructure and implication for infectious control. Lung 184: 373-374, 2006.

15. Gralton J and McLaws ML: Protecting healthcare workers from pandemic influenza: N95 or surgical masks? Crit Care Med 38: 657-667, 2010.

16. Aiello AE, Murray GF, Perez V, Coulborn RM, Davis BM, Uddin M, Shay DK, Waterman SH and Monto AS: Mask use, hand hygiene, and seasonal influenza-like illness among young adults: a randomized intervention trial. J Infect Dis 201: 491-498, 2010 . 